Volume 2 Nomor 2, Juli-Desember 2018: hlm. 101-110.

Magister Ilmu Hukum, Fakultas Hukum, Universitas Lampung,

Bandar Lampung, Lampung, Indonesia.

E-ISSN: 2598-3105 P-ISSN: 2723-2581

http://jurnal.fh.unila.ac.id/index.php/cepalo

\title{
KAJIAN SOSIOLOGIS PENYIMPANGAN TINDAKAN SUNTIK PEMUTIH KULIT YANG DILAKUKAN OLEH TENAGA KEBIDANAN
}

\author{
SOCIOLOGICAL STUDY OF IRREGULARITIES IN SKIN BLEACHING INJECTIONS \\ PERFORMED BY MIDWIFERY WORKERS
}

\section{Putu Diana Putri}

Dinas Kesehatan Provinsi Lampung

Putu.putri1036@students.unila.ac.id

\begin{abstract}
Abstrak
Bidan adalah wanita yang telah berhasil menempuh sekolah bidan yang sudah terdaftar sesuai ketentuan perundang-undangan. Profesionalitas bidan memiliki tiga kerja utama, yaitu melayani kesembuhan wanita hamil, melayani kesehatan anak, dan melayani kesehatan reproduksi wanita dan KB. Tetapi didalam praktik dijumpai sejumlah yang melakukan kegiatan diluar diluar ketiga fungsi utamanya yang mengandung zat antioksidan, utamanya berupa vitamin $C$ dosis tinggi (1000 s/d 4000mg) yang dicampur dengan glutation (600mg). Banyak juga yang menambahkan plasenta, baik yang berasal dari manusia maupun hewan, yang halal (sapi) atau haram (babi). Campuran zat tersebut disuntikan ke pembuluh darah yang ada di otot tangan atau lengan.Bahkan ada pula yang disuntikan melalui wajah pasien. Praktik penyimpangan ini, jelas tidak dibenarkan karena tidak sesuai dengan fungsi utama bidan. Namun dalam kenyataan sehari-hari praktik illegal ini terus berlangsung. Penulis tertarik untuk mengkaji masalah ini dari sisi sosiologis, apakah dengan berpedoman pada pertanyaan: apakah mendorong praktek ini dilakukan oleh seorang bidan, dan tidak menghukum apakah terjadi praktek inilah kami.
\end{abstract}

Kata Kunci: Peraturan Kesehatan, Penyelewengan, Tenaga Kebidanan, Suntik Pemutih Kulit.

\begin{abstract}
Midwives are women who have successfully attended midwifery schools that have been registered in accordance with statutory provisions. The professionalism of midwives has three main tasks: serving the healing of pregnant women, serving children's health, and serving women's reproductive health and family planning. But in practice there are a number of activities outside of the three main functions that contain antioxidants, mainly in the form of high doses of vitamin C (1000 to $4000 \mathrm{mg}$ ) mixed with glutathione (600 mg). Many also add placenta, both those from humans and animals, which are halal (cow) or haram (pig). A mixture of these substances is injected into a vein that is in the muscles of the hand or arm. Some are even injected through the patient's face. This practice of deviation is clearly not justified because it does not fit into the main function of the midwife. But in reality everyday this illegal practice continues. The author is interested in studying this problem from a sociological point of view, whether it is guided by the question: whether encouraging this practice is carried out by a midwife, and not punishing whether this practice occurs we are.
\end{abstract}

Keywords: Health Regulations, Deviations, Midwifery, Skin Whitening Injections.

Cara Mengutip (How to Cite): Putu Diana Putri, "Kajian Sosiologis Penyimpangan Tindakan Suntik Pemutih Kulit yang Dilakukan oleh Tenaga Kebidanan”, Jurnal Cepalo, 2 (2), (2018): 101-110.

DOI: https://doi.org/10.25041/cepalo.v2no2.1767

\section{A. Pendahuluan}

Berdasarkan Peraturan Menteri Kesehatan Nomor 28 Tahun 2017 tentang Izin dan Penyelenggaraan Praktik Bidan, bidan adalah seorang wanita yang lulus dari pendidikan bidan yang telah teregistrasi sesuai 
dengan peraturan perundang-undangan. Kemampuan bidan adalah salah satu kemampuan dalam bidang kesehatan yang mempunyai lisensi menjalankan pelayanan pengurusan kebidanan sesuai dengan kemampuan yang dimilikinya. Tenaga kebidanan dalam menjalankan tugasnya harus mempunyaii Surat Tanda Registrasi Bidan (STRB) dan Surat Izin Praktik Bidan (SIPB). Surat Tanda Registrasi Bidan adalah bukti tercatatnya seorang bidan yang diberikan izin oleh pemerintah kepada bidan yang telah memiliki sertifikat kompetensi sesuai dengan ketentuan peraturan perundang-undangan, sementara Surat Izin Praktik Bidan adalah bukti tertulis yang diberikan oleh pemerintah daerah kabupaten/kota kepada bidan sebagai pemberian kewenangan untuk menjalankan pelaksanaan kebidanan.

Berdasarkan Pasal 18 Undang-Undang Nomor 28 Tahun 2017 tentang Izin dan Penyelenggaraan Praktik Bidan, tenaga kebidanan hanya memiliki tiga (3) kewenangan, yaitu berkenaan dengan pelayanan kesehatan ibu, pelayanan kesehatan anak, dan pelayanan kesehatan reproduksi perempuan dan keluarga berencana. ${ }^{1}$ Tenaga kebidanan dapat melakukan tindakan kegawatdaruratan apabila tidak terdapat tenaga kesehatan lain di wilayah tempat bidan bertugas, hal tersebut diatur dalam Pasal 23 Ayat (1) huruf b. Lebih jelasnya mengenai tindakan kegawatdaruratan diperinci pada Pasal 26, bahwa kewenangan karena tidak adanya tenaga kesehatan lain di suatu wilayah tempat bidan bertugas sebagaimana dimaksud dalam Pasal 23Ayat (1) huruf b tidak berlaku, apabila telah terdapat ahli kesehatan lain dengan kemampuan dan kewenangan yang legal.

Seiring berkembangnya zaman, semakin beranekaragamnya kebutuhan masyarakat, ahli kesehatan terutama ahli kebidanan diminta tetap melaksnaakan tugas sesuai dengan kewajiban yang dimiliki. Walaupun pada kenyataannya, permintan itu tidak sejalan dengan praktiknya beberapa orang ahli kesehatan yang melakukan aksi yang tidak sesuai dengan tugas pokok dan peranannya, contohnya semacam kasus ahli kebidanan yang menjalankan perbuatan suntik pemutih kulit. Tenaga kesehatan telah memiliki batasan kewenangannya sendiri, begitu juga dengan tenaga kebidanan. Ahli kebidanan yang melakukan kewenangan yang tidak benar dengan ketentuan yang berlaku seperti menjalankan perbuatan suntik pemutih kulit yang diduga telah melanggar ketentuan profesi yang merekamiliki. ${ }^{2}$ Suntik Pemutih pada dasarnya berisi meliputi zat antioksidan. Antioksidan utamanya adalah seperti vitamin C dosis tinggi (1000 s/d 4000mg) dilarutkan dengan glutation (600mg), ada juga yang mencampurkan dengan plasenta, yaitu tali pusar bayi untuk mengembangkan sel-sel baru yang muda. Plasenta bisa berasal dari manusia atau hewan, baik yang halal (sapi) atau haram (babi), padahal zat ini fungsi utamanya bukan untuk pemutih kulit. Campuran zat tersebut kemudian disuntikan ke dalam tubuh, melalui injeksi pada otot bokong (intramuskuler), langsung ke pembuluh darah balik (intravena/infuse), bahkan disuntikan melalui wajah pasien. Suntik memutihkan kulit juga dapat memperlambat pembentukan melanin yang justru menbentuk kulit terlihat lebih kusam, tetapi dengan melakukan suntik putih secara tidak langsung kulit menjadi ditekan untuk bekerja secara tidak normal yang dapat membawa kerusakan bagian pada kulit. ${ }^{3}$ Akibat yang dapat di derita ketika tubuh terlalu seing menerima suntikan vitamin $\mathrm{C}$ biasanya dapat seperti migran, nyeri bagian perut, mual, tidak bisa tidur, diare, perut kembung dan batuginjal.Penggunaan vitamin $\mathrm{C}$ jangka panjang juga dapat menyebabkan ketergantungan. ${ }^{4}$

Setiap praktik yang dilaksanakan oleh ahli kesehatan telah diatur pada Undang-Undang Nomor 36 Tahun 2014 tentang Tenaga Kesehatan, khususnya ditekankan pada Pasal 26 ayat 1, dimana setiap tenaga kesehatan wajib menjalankan tugas sesuai kompetensi dan kewenangannya. Perbuatan seorang bidan yang melakukan praktiknya tidak sesuai kewenangannya, disebut juga sebagai sebuah tindakan melawan hukum, Van Bemmelen memberikan pengertian mengenai tindakan melawan hukum sebagaiberikut: ${ }^{5}$

1. Bertentangan dengan ketelitian;

2. Bertentangan dengan kewajiban;

3. Melakukan tindakan tanpahak;

4. Bertentangan dengan hak oranglain;

5. Bertentangan dengan hukum.

Atas perbuatan ahli kebidanan melangsungkan perbuatan suntik pemutih kulit, pasien adalah pihak yang paling dirugikan. Ketika seorang pasien mengalami reaksi negatif atas tindakan suntik pemutih kulit, pasien

\footnotetext{
${ }^{1}$ Farodis Zian, Panduan Lengkap Manajemen Kebidanan, Yogyakarta: D-Medika (Anggota Ikapi), (2012), hlm. 110.

${ }^{2}$ Sri Siswati, Etika dan Hukum Kesehatan Dalam Perspektif Undang-Undang Kesehatan, Depok: RajaGrafindo Persada, (2013), hlm. 184.

${ }^{3}$ Vitamin C dan Collagen, http://adelebeautyshop.com. Vitamin C dan Collagen, diakses pada 16 Oktober 2017 pukul 10.01 WIB.

${ }^{4}$ Melisa V. Kembuan, "Peran Vitamin C TerhadapPigmentasi Kulit", Jurnal Biomedik, Vol. 4, No. 3, (2012), hlm. 13-17.

${ }_{5}^{5}$ Alexandra Indrayanti Dewi, Etika Dan Hukum Kesehatan Cetakan I, Yogyakarta: Pustaka Book Publisher, (2008), hlm. 18.
} 
bukan hanya mengalami kerugian secara materil, namun mendapatkan kerugian immateril seperti penderitaan kesakitan, kesedihan, rasa ketakutan, tidak mendapatkan kebahagiaan/kebanggaan hidup, kehilangan bagian tubuh atau luka tubuh, kehilangan harapan sembuh atau normal, cacat fisik atau mental, bahkankematian. ${ }^{6}$ Berdasarkan pemahaman yang telah disampaikan pada latar belakang di atas, yang menjadi persoalan dalam penulisan ini adalah mengetahui kedudukan dan ahli kebidanan dalam tugas melakukan layanan kesehatan. Fokus penelitian berikutnya ialah mengetahui sejauh mana tenagakebidanan dapat menjalankan perbuatan di luar kekuasaan yang mereka punyai. Poin terakhir adalah menganalisa mekanisme hukuman yang diberikan ketika seorang bidan menjalankan perbuatan yang tidak sama dengan tugas dan tanggung jawabnya. Pendekatan masalah yang digunakan dalam penelitian ini adalah pendekatan empiris yang mengutamakan data primer. Analisis data menggunakan analisis kualitatif untuk memperoleh simpulan sebagai jawaban atas permasalahan penelitian.

\section{B. Pembahasan}

\section{KarakteristikNarasumber}

Narasumber dalam pengkajian ini berjumlah 17 orang, dengan rincian sebagai berikut:

a. Pasien suntik pemutih kulit 5orang

b. Dokter 2orang

c. Bidan yang tidak menjalankan perbuatan suntik putih kulit 8orang

d. Bidan yang menjalankan perbuatan suntik putih kulit 2orang

Penelitian ini menggunakan teknik Purposive Sampling, Narasumber dalam penelitian ini tidak disebutkan identitasnya. Hal ini bertujuan untuk menjaga privasi narasumber.

\section{Peran dan Tugas Tenaga Kebidanan Dalam PelayananKesehatan}

Ahli kebidanan mempunyai 3 kekuasaan yang berhubungan dengan pemberian fasilitas kesembuhan wanita hamil, melayani kesehatan anak, dan melayani kesehatan reproduksi wan dan KB. Ketika seorang bidan melakukan tindakan di luar ketiga aspek tersebut maka ahli kebidanan dilihat telah melanggar kode profesi yang mereka punyai. Segala tindakan yang dilakukan oleh tenaga kebidanan harus berasaskan kemanusiaan demi kepentingan dan kebaikan masyarakat khususnya tentang keselamatan ibu dan anak. Tenaga kebidanan dilarang melakukan tindakan di luar kewenangannya apalagi dengan alasan mendapatkan keuntungan. Hal tersebut diatur dalam Undang-Undang Nomor 36 Tahun 2009 tentang Kesehatan Pasal 23 Ayat 4, yaitu selama memberikan pelayanan kesehatan, tenaga kesehatan dilarang memprioritaskan kepentingan yang bernilaifinancial.

Ahli kebidanan dalam melakukan perannya, harus menjalankan perbuatan sesuai dengan Standar Asuhan Kebidanan, sesuai dengan Peraturan Menteri Kesehatan Nomor 938 Tahun 2007. Standar Asuhan Kebidanan adalah materi dalam metode penutipan keputusan dan perbuatan yang dijalankan oleh bidan sesuai dengan kewenangan dan ruang lingkup pelaksanaannya berdasarkan ilmu dan teknik kebidanan. Standar asuhan kebidanan berfungsi untuk menumbuhkan mutu ahli kebidanan dan menjauhkan praktik licik yang dijalankan oleh ahli kebidanan. Tenaga kebidanan dalam menjalankan tugasnya harus mencukupi peraturan sebagai berikut: ${ }^{7}$

a. Kode etik;

b. Standar profesi;

c. Hak penggunaan layanankesehatan;

d. Standar layanan; dan

e. Standar proseduroperasional.

Pada penelitian ini, peneliti memiliki 5 orang pasien suntik putih kulit yang ditujukan sebagai narasumber, pada narasumber pertama mengungkapkan bahwa:

"Pada permulaannya saya melihat rekan, dahulu warna kulitnya hitam. Tetapi ketika kemarin bertemu saat reuni, warna pigmen kulitnya menjadi lebih bersih dan terlihat lebih putih. Esok Harinya saya berusaha mengirimkan pesan lewat whatsapp berupaya bertanya tentang perubahan warna kulitnya saat ini. Awalnya rekan saya tidak mau mengatakan sejujurnya, tetapi akhirnya dia membenarkan jika dia melakukan suntik pemutih kulit. Saya bertanya lokasi menjalankan suntik pemutih tersebut dan mulai teratur melakukan suntik

\footnotetext{
${ }^{6}$ Machli Riyadi dan Lidia Widia, Etika \& Hukum Kebidanan, Yogyakarta: Nuha Medika, (2017), hlm. 128.

${ }^{7}$ Soekidjo Notoatmodjo, Etika \& Hukum Kesehatan, Jakarta: Rineka Cipta, (2010), hlm. 105.
} 
pemutih kulit. Awalnya saya melakukan suntik seminggu 4 kali, saya menganggap badan saya sekarang memang menjadi lebih putih, tetapi lokasi saya menjalankan suntik mengatakan bahwa badan, walaupun sudah melakukan suntik pemutih kulittidaktentu bisa lebih putih dibandingkan lengan bagian dalam. Saya merasakan bahwa hasil yang saya inginkan saat ini sudah cukup bagus. Akan tetapi sekarang saya mulai mengurangi melakukan suntik pemutih, yaitu 2 kali dalam satu minggu. Tindakan tersebut saya lakukan karena saya bekerja di lapangan, sehingga terkadang kurang rutin minum air putih, saya menanggap agak ragu jika tidak setiap saat meminum air putih tetapi terlalu banyak melakukan suntik pemutih maka organ ginjal saya akan rusak. Saya melakukan tindakan suntik pemutih tersebut dengan seorang bidan yang telah memiliki banyakpasien".

Pada informa kedua tersebut justru mendapatkan kondisi yang tidak memuaskan, yaitu: "Pada awal saya merasa berminat untuk melakukan suntik pemutih, dikarenakan mengetahui pendapat orang-orang yang mempunyai kulit mulus dan bercahaya setelah melakukan suntik pemutih kulit. Keinginan saya agar mendapatkan rasa percaya diri saat memakai gaun atau celana pendek. Dari media sosial Instagram, saya coba untuk mengirimkan pesan kepada agen jasa suntik pemutih, setelah mendapatkan alamat lokasi melakukan suntik pemutih kulit, saya mencoba mendatangi rumahnya. Saya agak merasa menyesal karena sebenarnya pelaku suntik pemutih tersebut melakukan perbuatan suntik putih dikamar tidurnya yang menurut saya dalam keadaan cukup tidak bersih dan membuat saya sedikit merasa tidak enak. Namun saya mencoba menahan diri dan mengira bahwa ini adalah cara yang baik bagi saya untuk mendapatkan kulit yang putih. Reaksi pada pertama-tama yang saya rasakan ketika suntikan masuk separuh, tangan saya terasa sangat gatal. Saya mencoba bertanya pada pihak yang bersangkutan suntik pemutih kulit dan dia hanya menjawab bahwa kemungkinan saja ini salah satu reaksi obatnya sedang bekerja. Rasanya seperti gatal agak panas yang membuat sangat merasa tidak enak di kulit saya, dan kemudian muncul bercak-bercak kemerahan pada kulit saya. Akhirnya sampai dirumah saya mencoba meminum antibiotik, tindakan tersebut disebabkan karena saya merasa agak tidak enak badan setelah mencoba suntik pemutih kulit. Bahkan setelah melakukan suntik putih saya langsung terkapar dirumah karena merasa demam. Dua hari kemudian pelaku suntik pemutih tersebut mengirimkan pesan kepada saya, memberikan jadwal suntik, dan saya langsung menyetujui. Namun karena sama-sama sibuk, dan keluarga tidak memberikan izin untuk saya melakukan suntik seperti itu, kami akhirnya bertemu di dekat rumah saya. Namun kali ini lebih mengesalkan, karena suntik pemutih dilakukan dimobilnya, dan dia melakukan tindakan tanpa menggunakan sarung tangan. Akhrinya saya berfikir, Apakah saya melakukan pembayaran dengan harga mahal tetapi kenapa melakukannya secara asal-asalan seperti ini. Pada akhirnya setelah melakukan tiga kali suntikan, saya memutuskanberhenti.Saya merasa warna kulit saya tidak berubah, namun saya justru merasa tersiksa karena alergi, saya merasa rugi dan tidak akan melakukan suntik putih lagi. ${ }^{9}$

Selanjutnya, hasil pembicaraan penulis dengan narasumber ke-tiga, yaitu:

"Dahulu saya pernah melakukan suntik pemutih kulit, dan yang saya rasakan biasa saja, hanya saja kulit terasa lebih bersih. Namun ketika saya berhenti melakukan suntik pemutih, maka pigmen kulit saya akan balik lagi seperti saat saya belum melakukan perbuatan suntik putihkulit. Setelah melakukan suntik pemutih, tindakan yang harus saya jalankan harus minum satu gelas air putih, jika tidak dijalankan hal tersebut sangat berakibta fatal untuk ginjal. Saya melakukan suntik pemutih kulit dengan bidan yang jarak tugasnya dekat dengan rumah saya, saya membeli sendiri obat-nya lalu saya cuma perlu membayar jasa suntik yang hanya 10ribu rupiah. Awalnya saya memakai 5 ampul/minggu, namun selanjutnya hanya 2 minggu sekali. Isi tiap box adalah 10 ampul. Saya mencoba vitamin dan collagen dengan harapan agar pertahanan kekebalan tubuh saya menjadi lebih bertenaga dan memiliki pigmrn kulit yang sedikit lebih putih". ${ }^{10}$

Pada narasumber ke-empat, mempunyai tujuan yang hampir sama dengan tujuan narasumber ketiga dalam mencoba suntik putih kulit yaitu:

"Saya mencoba suntik vitamin $\mathrm{C}$ yang digabung bersamaan dengan gluthation. Akan tetapi sangat beda dengan orang pada umumnya yang menjalankan suntik pemutih untuk mendapatkan kulit yang bersih. Saya malah mencobanya untuk mendapatkan tubuh yang terasa lebih sehat. Tindakan tersebut saya coba karena saya baru terserang penyakit thypus dan tubuh terkadang terasa lebih cepat lemas. Nilai lebih dari suntik putih adalah tubuh saya terasa lebih lembut. Namun bukannya mendapatkan tubuh yang sehat, saya malah ketergantungan dengan suntikan ini. Ketika saya coba untuk tidak mencoba lagi, tubuh saya merasa sangat

\footnotetext{
${ }^{8}$ Wawancara dengan Pasien Pengguna Jasa Suntik Putih, pada tanggal 15 Oktober 2017, pukul 12.02 WIB.

${ }^{9}$ Wawancara dengan Pasien Pengguna Jasa Suntik Putih, pada tanggal 17 Oktober 2017, pukul 11.03 WIB.

${ }^{10}$ Wawancara dengan Pasien Pengguna Jasa Suntik Putih, pada tanggal 18 Oktober 2017, pukul 14.02 WIB.
} 
lemas. Agak lama saya merasa tidak nyaman dikarenakan pengaruh dari suntik putih ini, pada akhirnya sampai saat ini saya bisa lepas dari pengaruh tersebut". ${ }^{11}$

Selanjutnya alasan narasumber ke-lima mencoba suntik putih adalah:

"Saya mencoba suntik putih kulit karena mengikuti saran sahabat, tindakan tersebut juga dikarenakan mengetahui para wanita mencoba tenaga suntik putih kulit. Pertama saya hanya ingin mencoba karena saya tidak mengetahui efek mencoba suntik putih kulit. Pada akhirnya keluarga saya mendapati bahwa saya mencoba jasa suntik pemutih dan menegur saya dengan keras dan saya berhenti melakukan suntik putih tersebut". ${ }^{2}$

Berhubungan dengan adanya kabar hukum suntik pemutih kulit yang dijalankan oleh ahli kebidanan, peneliti mencoba melakukan perbincangan dengan 2 orang dokter. Dokter pertama adalah dokter yang bertugas di sebuah rumah sakit Tulang Bawang, dokter pertama menyatakan bahwa:

"Sebuah perbuatan memasukkan larutan suntik putih kulit yang dijalankan oleh seorang bidan adalah perbuatan yang salah. Dikarenakan pada aturannya ahli kesehatan telah mempunyai hak dan kewajiban yang dengan jelas telah terdapat dalam UU No. 36 tentang Tenaga Kesehatan. Bahwa untuk menjalankan perbuatan penyuntikan pada orang yang bukan ibu dan anak, seorang ahli kebidanan harus menjalankannya dengan mempunyai izin dari seorang dokter. Dengan pengertian lain bahwa seorang tenaga bidan hanya bisa menjalankan perbuatan penyuntikan yang setara dengan ruang lingkup kekuasaannya, contohnya saja memberikan suntik imunisasi pada balita. Secara garis besar, seorang tenaga kebidanan hanya mempunyai kewenangan pada ibu (baik dalam proses persiapan kehamilan hingga melahirkan), anak (dalam proses melahirkan dan ASI), dan tentunya pada proses KB (dalam bentuk memberikan obat atau memasang alat $\mathrm{KB})$. Itu hanya apabila menunjang jalannya kelahiran dan hanya dalam keadaan genting seperti bayi sungsang, atau ibu mengalami pendarahan, maka tenaga bidan harus memberi surat rujukan kepada pihak rumahsakit". ${ }^{13}$

Informan kedua adalah narasumber yang baru saja disumpah dokter, dan sedang menjalankan internship. Narasumber kedua menyatakan bahwa:

"Hal tersebut sangat tidak benar untuk dilakukan. Bahkan saya yang sudah disumpah dokter, tidak mempunyai hak untuk memberikan perintah sembarangan kepada bidan atau perawat untuk menyuntikan apapun, apalagi obat yang bisa untuk memutihkan kulit. Sampai hari ini saya tidak mempunyai wewenang ketika menyuntik pasien sembarangan tanpa izin dan pengawasan dari dokter senior saya. Ada pengertiannya penyakit SJS dalam ilmu kesehatan atau orang awam nyebutnya steven johnson syndrome, itu salah satu adalah penyakit yang sangat berbahaya dan bisa menghilangkannyawa". ${ }^{14}$

Tidak semua ahli kebidanan menjalankan perbuatan tanpa wewenang seperti yang telah dijalankan oknum bidan yang menjalankan perbuatan suntik putih kulit, ada segelintir bidan yang tidak menjalankan perbuatan suntik pemutih kulit hanya merasa perbuatan tersebut adalah perbuatan yang tidak patut dijalankan, diantaranya berpendapat bahwa:

"Perbuatan bidan menjalankan suntik putih kulit adalah perbuatan yang dapat dislaahkan. Menurut saya tindakan tersebut tidak benar dijalankan oleh ahli kesehatan kebidanan. Dikarenakan banyak resiko yang disebabkan dari suntik pemutih kulit, diantaranya gagal ginjal. Menurut saya, yang boleh melakukan perbuatan suntik pemutih hanya dokter dan cara tersebut harus dilakukan oleh dokter yang mempunyai lisensi dikeahliannya. Hanya itu harus diingat juga bahwa seorang tenaga kesehatan tersebut harus mempunyai lisensi praktik. Seorang bidan menjalankan perbuatan suntik putih kulit hanya dilandasi oleh kepercayaan diri sendiri bahwa mereka sudah terbiasa melakukan praktik dengan meggunakan jarum suntik dan pasien tidak akan mengalami dampak yang buruk jika seorang melakukan tindakan suntik pemutih.Menurutpandangan saya, jika tenaga kebidanan dengan pasti melanggar peraturan dengan membuka usaha yang tidak ada hubungan dengan kompetensinya, maka surat ijin praktik bidan akan dicabut". ${ }^{15}$

Pada narasumber tenaga kebidanan ke-dua memberikan tanggapan:

"Menjalankan perbuatan suntik putih kulit memang bukanlah wewenang seorang bidan, tapi pada kenyataannnya masih banyak bidan-bidan yang menjalankannya dengan memperoleh keuntungan pribadi. Tetapi juga bagi tenaga kebidanan tidak diizinkan melakukan praktik suntik putih kulit karena itu melanggar kode etik profesi bagi seorang bidan dan tidak masuk kedalam kewewenangan dan kewajiban ahli kebidanan.

\footnotetext{
${ }^{11}$ Wawancara dengan Pasien Pengguna Jasa Suntik Putih, pada tanggal 20 Oktober 2017, pukul 13.02 WIB.

${ }^{12}$ Wawancara dengan Pasien Pengguna Jasa Suntik Putih, pada tanggal 20 Oktober 2017, pukul 14.25 WIB.

${ }^{13}$ Wawancara dengan dokter, pada tangga 10 Oktober 2017, pukul 10.05 WIB.

${ }^{14}$ Wawancara dengan dokter, Pada tanggal 12 Oktober 2017, pukul 15.02 WIB.

${ }^{15}$ Wawancara dengan bidan yang tidak melakukan tindakan suntik pemutih, pada tanggal 15 Oktober 2017, pukul 12.02 WIB.
} 
Dengan kata lain bidan tidak harus melakukan suntik putih kulit bagi seorang pasien adalah karena bidan tidak diizinkan menyuntikkan obat melalui IV (Intravena) tanpa perintah dari seorang dokter. Tapi, kembali lagi pada hak pasien menentukan apakah mereka akan melakukan perbuatan suntik pemutih lewat bidan atau dokter. Pasien yang pintar pasti akan memilih ahli yang lebih berpengalaman dan juga pasti harganya tidak murah. Sanksi yang diberikan ketika seorang bidan terbukti menjalankan perbuatan suntik putih kulit pasti akan diberikan sanksi administrasi, tetapi bisa juga dikenakan sanksi pidana jika pasien merasa tidak diuntungkan". ${ }^{16}$

Narasumber bidan ke-tiga memberikan jawaban:

"Menurut pendapat dia suntik putih diperbolehkan dilakukan, apabila dosis, cara penyuntikan, dan penggunaannya yang tepat. Tetapi jika sudah digunakan secara tidak benar dan pemakaiannya, perbuatan tersebut justru akan mengakibatkan dampak yang buruk untuk tubuh. Tetapi perlu diingat juga, bahwa yang diperbolehkan melakukan perbuatan tersebut hanya seorang dokter dan bidan yang sangat berkompeten. Mungkin memberi manfaat yang bagus, Tetapi kalua menurut saya suntik putih pada intinya sangat tidak baik dan mempunyai banyak dampak negatif bagi tubuhkita". ${ }^{17}$

Narasumber bidan ke-empat memberikan tanggapan:

"Menurut penglihatan saya, seorang bidan yang melakukan perbuatan suntik pemutih kulit harus di beri sanksi yang memberatkannya. Perbuatan tersebut dikarenakan oknum tersebut merusak nama baik tenaga bidan, tetapi juga jika suatu hari sampai ada korban dan perbuatan tersebut tindakan bidan yang melakukan tindakan diluar kekuasaannya. Tetapi jarang sekali kita mendengar terdapat kasus tentang suntik pemutih, namun bukan berarti seorang bidan boleh menjalankan perbuatan tersebut dan menganggap imun pasien sama, karena sistem imun pasien yang satu pasti berbeda dengan yang lain. Akan tetapi ada resiko jika seorang pasien ternyata mempunyai alergi akut, dan pada akhirnya memang pasien melaporkan tindakan tersebut kepada pihak yang berwajib adalah bidan itusendiri". ${ }^{18}$

Narasumber bidan ke lima memberikan tanggapan bahwa:

"Perbuatan bidan melakukan suntik pemutih kulit memang salah, tetapi juga perbuatan tersebut bisa terjadi juga efeknya sangat kecil pemerintah dan pihak berwajib berkaitan dalam menindaklanjuti hal ini. Dalam perbuatannya, suatu perbuatan tidak akan ditangani dan diberantas apa bila belum ada korban yang jatuh. Seorang bidan yang apabila terbukti bersalah melakukan perbuatan suntik putih kepada pasien, biasanyahanya akan diberikan sanksi administratif berupa hanya diberikan peringatan bahkan sampai pencabutan STR/SIPB". ${ }^{19}$

Narasumber bidan ke-enam memberikan tanggapan bahwa:

"Tenaga kebidanan yang membuka usaha suntik putih secara individu memang sangat bersalah, dalam artian tindakan yang dilakukannya adalah tindakan ilegal. Dikarenakan pada awalnya seorang bidan kurang memahami apa saja sebenarnya kandungan obat pemutih tersebut, danapadampaknya bagi kesehatan pasien. Jika sewaktu-waktu pasien mengalami resiko dari suntik putih yang mengakibatkan dampak buruk, dan tentunya bidan lah yang harus bertanggung jawab dari tindakan yang ditimbulkan. Tindakan tersebut karena bidan biasanya hanya menangani ibu melahirkan atau yang berkenaan dengan ibu hamil, anak, dan KB. Bukan masalah yang ditimbulkan, atau mendesak lainnya yang diakibatkan suntikpemutih". ${ }^{20}$

Narasumber bidan ke-tujuh memberikan pendapatnya bahwa:

"Alasan yang tidak dibenarkan apapun itu apabila seseorang ahli kesehatan melakukan perbuatan diluar dari apa yang harus melakukan mereka lakukan. Apalagi tindakan tersebut bisa membahayakan keselamatan pasien. Oleh karena itu, untuk meminimalisir adanya praktik ilegal yang dilakukan ahli kebidanan, bahkan seorang pasien juga harus bisa mencermati untuk memilih lokasi dan mencermati siapa yang melakukan perbuatan, agar mereka tidak akan membuka usaha tersebut jika tidak ada pasien yang akan menggunakan jasa mereka., 21

Narasumber bidan ke delapan memberikan penjelasan bahwa:

"Bidan bukan hanya bertanggung jawab atas keselamatan ibu dan bayi, jika sampai melakukan tindakan yang diluar kapasitasnya, ia juga harus mendapat pengawasan dari orang yang berpengalaman di bidang tersebut, dengan maksud lain bidan memang tidak di izinkan melakukan perbuatan suntik pemutih kulit

\footnotetext{
${ }^{16}$ Wawancara dengan bidan yang tidak melakukan tindakan suntik pemutih, pada tanggal 17 Oktober 2017, pukul 19.05 WIB.

${ }^{17}$ Wawancara dengan bidan yang tidak melakukan tindakan suntik pemutih, pada tanggal 18 Oktober 2017, pukul 16.03 WIB .

${ }^{18}$ Wawancara dengan Bidan yang tidak melakukan tindakan suntik pemutih, pada tanggal 20 Oktober 2017, pukul 09.30 WIB

${ }^{19}$ Wawancara dengan bidan yang tidak melakukan tindakan suntik pemutih, pada tanggal 20 Oktober 2017, pukul 13.02 WIB.

${ }^{20}$ Wawancara dengan bidan yang tidak melakukan tindakan suntik pemutih, pada tanggal 21 Oktober 2017, pukul 10.00 WIB.

${ }^{21}$ Wawancara dengan bidan yang tidak melakukan tindakan suntik pemutih, pada tanggal 23 Oktober 2017, pukul 19.00 WIB.
} 
dengan dasar apapun. Oknum bidan yang tidak bertanggung jawab seperti itu perlu dikenakan hukumans, karena mereka secara tidak langsyng telah melanggar kode etik kebidanan dan tentunya akan merusak nama baik ahli kebidanan".22

Berdasarkan delapan pendapat narasumber yang memang adalah tenaga kesehatan kebidanan yang tidak membuka atau melakukan praktik suntik pemutih tersebut, bagi bidan melakukan perbuatan suntik putih kulit yang pada dasarnya bukanlah menjadi wewenang dan tanggung jawab seorang bidan. Narasumber juga memberikan penjelasan bahwa sangat banyak sekali kasus suntik pemutih kulit yang dijalankan oleh bidan dan diakibatkan oleh kurangya pengawasan dari pihak berwajib, mereka menganggap seolah bahwa kenyataannya bukanlah suatu yang perlu diawasi dengan tegas, yang nantinya akan ada pasien yang menjadi korban. Narasumber juga sangat berharap orang orang harus lebih memahami dalam memilih lokasi melakukan suntik pemutih kulit, dan tidak berharap lebih akan pernggunaannya yang bisa memberikan dampak yang sangat buruk bagi kesehatan pasien.

Pada penelitian ini, kami berusaha untuk mencari pandangan narasumber ahli kebidanan yang melakukan perbuatan suntik pemutih kulit, tindakan tersebut dijalankan untuk lebih memberikan penjelasan penelitian dan melihat alasan yang apa saja agar bisa melakukakn suntik putih. Pada penelitian ini, didapat dua narasumber tenaga kebidanan yang bersedia diminta keterangan narasumber tidak ingin untuk ditemui secara langsung dan bersedia diwawancara lewat media sosial Instagram dan dia minta untuk tidak menyebutkan identitasnya. Narasumber ahli kebidanan yang pertama menyatakan bahwa:

"Saya melakukan tindakan suntik putih dari satu tahun terakhir. Perbuatan tersebut saya jalankan karena suntik pemutih kulit sedang marak di kalangan wanita dan tentu saja usaha ini sangat memberikan keuntungan jika dijalankan. Alasan pokok saya memang lebih ke sudut finansial atau uang. Mencari manfaat dari perkembangan zaman, saya gunakan media social untuk menyebarkan jasa saya. Obat yang paling laku adalah glutax dan cindella, dengan harga 1-3 juta per paketnya. Bermodal keberanian dan kemampuan menyuntik, saya mulai membuka praktik ini dirumah. Menurut pendapat saya bahwa semua orang yang tidak memiliki pengalaman di bidang kesehatan juga bisa menjalankan hal tersebut ini jika mereka tahu soal jaringan intravena pasien. Yang saya tahu bahwa apa yang saya jalankan saat ini adalah perbuatan yang salah, tetapi dikarenakan banyak rekan seangkatan saya yang menjalankan praktik tersebut saya jadi sedikit menjadi aman. Dan ditambah dengan kurangnya pengawasan yang dilakukan oleh aparat. Saya juga merasa akan juga banyak orang yang membuka praktik dalam usaha ini jika memang pemerintan tidak mengawasi dengan khusus dan pengawasan yang cermat". 23

Pada narasumber kedua yang juga ahli kebidanan yang melakukan suntik pemutih kulit memaparkan bahwa: "Suntik pemutih kulit pada dasarnya tidak menimbulkan resiko jangka pendek kecualijika pasien mempunyai catatan medis yaitu alergi terhadap zat atau cairan tertentu. Sejauh ini saya juga belum pernah bertemu dengan pasien yang mendapatkan dampak yang parah, paling juga Cuma sebatas gatal ataupun muncul bercak-bercak merah. Apabila terjadi juga paling saya biasanya memberikan saran agar pasien untuk minum paracetamol sebagai antibiotik agar badan tidak lebih sakit. Saya kurang mengetahui perihal alergi akut, saya Cuma berfikir bahwa perbuatan tersebut adalah resiko dari obat yang sedang berjalan. Pada jangka panjang, suntik putih kulit memang dapat memberikan dampak buruk bagi kesehatan ginjal, oleh karena itu untuk mengurangi dampaknya kadang kami memberikan saran supaya pasien untuk segelas besar air putih sehabis mereka menjalankan suntik putih kulit. Tindakan tersebut juga dilakukan agar cairan dapat menyebar dengan baik didalam tubuh, dan juga tidak mengakibatkan pengendapan pada ginjal. Bukan hal yang wajar, jika memang semakin banyak orang yang ingin melakukan suntik pemutih kulit maka akan banyak juga oknum-oknum yang membuka usaha ini. Dan dengan kelebihan mendapatkan keuntungan". ${ }^{24}$

Dari kedua apa yang disampaikan oleh narasumber diatas bahwa ahli kebidanan yang menjalankan perbuatan suntik putih kulit, mereka sengaja melakukannya dengan cara ekonomi yang dilandaskan kepada minat suntik putih kulit yang popular akhir-akhir ini. Selain itu juga mereka dengan berani engembangkan jasa tersebut bahkan mengedarkan jasa mereka lewat media sosial dengan resiko kurangnya pengawasan dari pemerintah atas kasus ini. Seperti pemaparan dari ahli kebidanan yang tidak menjalankan praktik dari suntik pemutih di atas, sebuah kasus tidak mendapatkan pengawasan dan ditindak jika memang belum ada korban yang dirugikan oleh perbuatan tersebut.

\footnotetext{
${ }^{22}$ Wawancara dengan Bidan yang Tidak Melakukan Tindakan Suntik Pemutih, Pada Tanggal 23 Oktober 2017, Pukul 20.25 WIB.

${ }^{23}$ Wawancara dengan bidan yang melakukan tindakan suntik pemutih, pada tanggal 25 Oktober 2017, pukul 10.02 WIB.

${ }^{24}$ Wawancara dengan bidan yang melakukan tindakan suntik pemutih, pada tanggal 26 Oktober 2017, pukul 11.00 WIB.
} 


\section{Keadaan Ahli Kebidanan Dalam Melakukan Tindakan Di LuarWewenang}

Ahli kebidanan juga mempunyai kekhususan dalam menjalankan perbuatan di luar wewenangnya, yaitu dalam kondisi gawat darurat. Tetapi harus ada pengecualian juga tetap ada pada masalah pelayanan ibu, anak dan keluarga berencana dan bukan tentang masalah lainnya. Kondisi kegawat-daruratan diatur pada PMK 28 Tahun 2017 Pasal 20 Ayat 2 huruf b dimana bidan wajib melakukan tindakan kegawat-daruratan dengan perujukan. Tenaga kebidanan juga melakukan tindakan kegawat-daruratan apabila tidak terdapat tenaga kesehatan lain di wilayah tempat bidan bertugas, hal tersebut diatur dalam Pasal 23 Ayat (1) huruf b. Lebih jelasnya mengenai tindakan kegawat-daruratan diperinci pada Pasal 26, bahwa kewenangan karena tidak adanya tenaga kesehatan lain di suatu wilayah tempat bidan bertugas sebagaimana dimaksud dalam Pasal 23 Ayat (1) huruf $b$ tidak berlaku, apabila telah tersedia tenaga kesehatan lain dengan kompetensi dan kewenangan yang sesuai. Keadaan tidak adanya tenaga kesehatan lain tempat bidan bertugas ditetapkan oleh kepala dinas kesehatan kabupaten/kota dan hal tersebut dinyatakan pada Pasal 26 Ayat (2).

Ahli kebidanan hanya dibolehkan untuk memberikan penanganan kepada pasien yang mengalami bayi sungsang atau keadaan gawat lainnya tetapi juga melaksanakan harus sesuai dengan SOP yang mereka punyai dan alasam utama adalah untuk kesehatan ibu dan bayi. Hal tersebut juga dapat dijalankan hanya dengan alasan karena tidak adanya ahli kesehatan lain yang lebih cermat dan lokasi untuk mendatangi rumah sakit juga jauh dan akan menyebabkan dampak yang justru negatif jika tidak cepat ditangani. Segala alasan ahli kesehatan yang dapat disalahkan jika terdapat ahli kesehatan yang lain dan lokasi rumah sakit sangat dekat. Jika alasan yang tidak tepat dan terjadi segala sesuatu yang tidak diinginkan pada pasien maka dalam hal ini bidan dianggap telah melakukan kesalahan dan dapat diberikansanksi.

\section{Sanksi Bagi Tenaga Kebidanan yang Melakukan Tindakan Tidak Sesuaidengan Tanggung Jawab danKewenangannya}

Dalam menjalankan praktiknya, ahli kebidanan memiliki kebebasan yang diatur pada Pasal 29 Peraturan Menteri Kesehatan Nomor 28 Tahun 2017 tentang Izin dan Penyelenggaraan Praktik Bidan, yaitu:

a. Memperoleh perlindungan hukum sepanjang melaksanakan pelayanan sesuaidengan standar profesi, standar pelayanan, dan standar proseduroprasional;

b. Memperoleh informasi yang lengkap dan benar dari pasien dan/ataukeluarganya;

c. Melaksanakan tugas sesuai dengan kompetensi dan kewenangan;dan

d. Menerima imbalan jasaprofesi.

Dalam tindakannya bidan yang melaksanakan perbuatan suntik putih kulit diduga telah lenyapnya hak dalam mendapatkan payung hukum karena seorang bidan yang melakukan perbuatan suntik putih kulit melakukan tindakan yang tidak sesuai dengan kode etik profesi, standar pelayanan dan SOP yang mereka miliki, dan juga yang ahli kebidanan lakukan bukan demi alasan pokok bidan yaitu kesehatan ibu dan anak, tetapi lebih kepada mencari keuntungan materi, dengan alasan tersebut ahli kebidanan yang menjalankan perbuatan suntik pemutih kulit dapat diberikan hukuman sesuai dengan peraturan yang berlaku.

Pada dasarnya tindakan ahli kesehatan khususnya tenaga kebidanan harus dilaksanakan sesuai dengan aturan yang berlaku, apabila tidak sesuai maka mereka dapat dipersalahkan dan dapat dikenakan sanksi. Langkah utama yang akan dilakukan apabila seorang tenaga kebidanan melakukan tindakan penyalahgunaan wewenang adalah dengan memberikan sanksi administratif. Pada kasus melakukan tindakan suntik pemutih kulit, bidan dengan sangat jelas telah melanggar batasan atau peran yang mereka miliki. Sanksi administratif diharapkan mampu memberikan efek jera kepada beberapa oknum ahli kebidanan yang melakukan perbuatan tidak sesuai dengan tugas yang seharusnya mereka lakukan. Sanksi administratif bagi tenaga kebidanan yang melakukan tindakan suntik pemutih kulit diatur dalam Undang-Undang Tenaga Kesehatan Nomor. 36 Tahun 2014, Pasal 4. Sanksi administratif tersebut berupa teguran lisan, teguran tulisan bahkan sampai pencabutan izinpraktik.

Bagi ahli kebidanan yang menimbulkan resiko pada pasien atas perbuatannya akan diberikan sanksi perdata sesuai dengan Ketentuan Peraturan Perundang-Undangan, yang diatur dalam Undang-Undang Tenaga Kesehatan Tahun 2009 Pasal 58. Sementara upaya terakhir yang dapat ditempuh apabila sanksi administratif dan sanksi perdata tidak dapat menyelesaikan masalah adalah dengan memberikan sanksi pidana. Pada kasus bidan yang melakukan perbuatan suntik pemutih kulit yang menyebabkan pasien mengalami luka berat maka akan dipidana paling lama 3 tahun, dan apabila perbuatannya menyebabkan pasien meninggal, maka akan dipidana penjara paling lama 5 tahun, seperti yang diatur pada Pasal 84 Undang-Undang Tenaga Kesehatan Tahun 2009. 


\section{Penutup}

Tugas dan wewenang tenaga kebidanan hanya berkaitan dengan pemberian layanan kesehatan ibu, pemberian layanan kesehatan anak, dan pelayanan kesehatan reproduksi pada wanita dan keluarga berencana bukan untuk melakukan tindakan suntik pemutih kulit. Ahli kebidanan dapat melakukan perbuatan kegawatdaruratan jika tidak ada tenaga kesehatan lain diwilayah tempat bidan bertugas, dan hal tersebut diatur dalam Pasal 23 Ayat (1) huruf b. Lebih jelasnya berkenaan dengan perbuatan kegawat-daruratan diperinci pada Pasal 26, bahwa kewenangan karena tidak adanya tenaga kesehatan lain di suatu wilayah tempat bidan bertugas sebagaimana dimaksud dalam Pasal 23 Ayat (1) huruf b tidak berlaku, jika memang telah tersedia tenaga kesehatan lain dengan kompetensi dan wewenang yang sesuai. Seorang ahli kebidanan yang telah dibuktikan melakukan perbuatan suntik pemutih kulit dapat dikenakan hukuman, hukuman tersebut berupa sanksi administratif, sanksi perdata, hingga sanksi pidana. Sanksi administratif diharapkan mampu memberikan hukuman yang pantas kepada oknum tenaga kebidanan yang melakukan perbuatan tidak sesuai dengan tugas yang seharusnya mereka lakukan. Sanksi administratif bagi tenaga kebidanan yang melakukan tindakan suntik putih kulit diatur dalam Undang-Undang Tenaga Kesehatan Nomor. 36 Tahun 2014, Pasal 4. Sanksi administratif tersebut berupa teguran lisan, teguran tertulis bahkan sampai pencabutan izin praktik. Bagi ahli kebidanan yang menimbulkan resiko pada pasien atas perbuatannya akan diberikan sanksi perdata sesuai dengan Ketentuan Peraturan Perundang-Undangan, yang diatur dalam Undang-Undang Tenaga Kesehatan Tahun 2009 Pasal 58. Sementara upaya akhir yang dapat ditempuh apabila sanksi administratif dan sanksi perdata tidak dapat menyelesaikan masalah adalah dengan memberikan sanksi pidana.

\section{A. Buku}

\section{DAFTAR PUSTAKA}

Dewi, Alexandra Indrayanti. (2008). Etika danHukum Kesehatan Cetakan I. Yogyakarta: Pustaka BookPublisher.

Farodis, Zian. (2012). Panduan Lengkap Manajemen Kebidanan. Yogyakarta: D-Medika (Anggota Ikapi).

Notoatmodjo, Soekidjo. (2010). Etika \& Hukum Kesehatan. Jakarta: Rineka Cipta.

Riyadi, Machli dan Widia, Lidia. (2017). Etika \& Hukum Kebidanan. Yogyakarta: Nuha Medik. Siswati, Sri. 2013. Etika dan Hukum Kesehatan Dalam Perspektif Undang-Undang Kesehatan.Depok: RajaGrafindo Persada.

\section{B. Jurnal}

Melisa V. Kembuan, "Peran Vitamin C Terhadap Pigmentasi Kulit", Jurnal Biomedik, Vol. 4 No. 3, (2012).

\section{Peraturan Perundang-Undangan}

Keputusan Menteri Kesehatan Republik Indonesia Nomor 369 tahun 2007, tentang Standar Profesi Bidan. Peraturan Menteri Kesehatan Republik Indonesia 28 Tahun 2017 tentang Izin dan Penyelenggaraan Praktik Bidan.

Undang-Undang Nomor 36 Tahun 2009, tentang Tenaga Kesehatan Undang-Undang Nomor 36 Tahun 2014, tentang Tenaga Kesehatan.

\section{Sumber Lain}

Vitamin C dan Collagen, http://adelebeautyshop.com. 
